\title{
1
}

\section{Introduction: Civil Society, Public Debate and Natural Resource Management}

\author{
Indra Overland
}

\section{The Paradox of Plenty}

Between 1980 and 2015, the world produced altogether 980 billion barrels of oil, worth a total of USD 54 trillion. ${ }^{1}$ For the biggest exporterssuch as Russia, Saudi Arabia and the United Arab Emirates-oil has generated export revenues on a scale that other countries can only dream of. However, if these revenues are badly managed, not only do they go to waste, but the countries may be even worse off than they would have been otherwise. This is the 'paradox of plenty' (Karl 1997), which has become almost a cliché, giving rise to what Bebbington $(2013,4)$ calls a 'cottage industry' of publications on how natural resource wealth affects societies. ${ }^{2}$ There has been less interest in the opposite relationship: how different societal configurations influence the management of natural resources. This book therefore flips the independent and dependent variables of the resource curse literature, so that society becomes the

\section{Overland $(\bowtie)$}

Head of the Energy Programme, Norwegian Institute of International Affairs (NUPI), Oslo, Norway 
independent variable and the management of natural resource wealth the dependent variable.

The literature that does exist on this relationship holds that societal institutions are important for how natural resources are governed, but rarely goes into detail (see, e.g. Bulte et al. 2005; Mehlum et al. 2006). Many studies of institutions and the resource curse seek to determine whether institutions influence how resource revenues impact the economic development of countries. It mostly finds that having stronger institutions puts a country in a better position to handle its resource revenues. ${ }^{3}$ This amounts to a 'winner takes all' logic: countries that happen to have strong social and political institutions before the discovery of valuable natural resources are more likely to manage the ensuing revenues successfully-whereas countries without strong institutions in place before resource revenues start flowing are 'cursed'. 4 This argument has a fatalistic ring: what you have is what you get. The literature has less to say about why some countries have good institutions or how countries without such institutions might go about creating them. As Rosser (2006) noted, there is a lack of research into what specific social and political preconditions facilitate the good governance of natural resources.

Much of the literature does not even discuss how to define a 'strong' institution. In fact, some central works on institutions and the resource curse even fail to define what an 'institution' is in the first place-for example, Mehlum et al.'s (2006) much-quoted article 'Institutions and the Resource Curse'. This is surprising, since 'institution' may refer to anything from highly formalized events and organizational structures, such as elections and ministerial bureaucracies, to entirely informal patterns of cultural behaviour. (The narrower definition used in this book is presented towards the end of this chapter.)

\section{How Big Is Your Brain?}

With this book, I attempt to fill the gap in the literature by assessing the following hypothesis: it is not only formal aspects of institutions that are important for the success of natural resource governance but also their embeddedness in a conducive socio-political context and the dynamism 
of the long-term process of institution creation and re-creation. This implies that successful management of natural resources depends on freedom of speech, a dynamic and wide-ranging public debate through multiple independent media channels and an active civil society engaged in natural resource issues. Without these elements, a resource-rich country is less likely to develop appropriate and effective institutions for managing its resource wealth.

The hypothesis inspires a theoretical concept that I refer to as 'public brainpower'. The main pillar of public brainpower is polycentricity, or the coexistence of many different public actors freely expressing their views: individual citizens, political parties, trade unions, charities, companies, research institutes, religious institutions, the mass media and government institutions. The more polycentric a society is, the greater is its 'brainpower': its memory becomes more comprehensive and multifaceted, the various actors can perform quality control on each other's ideas and arguments, and it is more difficult to repress challenging thoughts. Above all, a polycentric society offers a broader base for creativity. Thus, the concept of public brainpower highlights the importance of creativity to successful long-term governance-a point often overlooked in the literature on governance and certainly in the literature on natural resource management.

The concept of public brainpower draws inspiration from the work by Almond and Verba (1965) on civic culture, by Dahl (1956, 1989) on polyarchy, by Habermas (1962) on the public sphere, and by Putnam (1995, 2000) and Putnam et al. (1994) on civil society and social capital. These classics provide theoretical inspiration beyond the narrower and more contemporary literature on institutions and the resource curse discussed above.

With their work on civic culture, Almond and Verba (1965) made a breakthrough in the study of political culture. They held that the populations of different countries have different attitudes and expectations towards the state and their own participation in its affairs, and that these attitudes determine how well states function. This is similar to the concept of public brainpower but involves a stronger element of cultural determinism. 
Polyarchy literally means 'rule by many' and was used by Dahl (1989, 220) to describe a political system that is open to contestation and in which many different actors, though not necessarily all, can influence the system. However, polyarchy relates primarily to elections and noncoercion in politics and to members of society as individuals with individual rights - none of which are major foci in this book. My interest is rather in the degree of multipolarity that exists in such a system and its contribution to good governance: how different social units contribute multiple competing voices to the governance of society and not only through the narrow confines of electoral politics.

The concept of public brainpower is also closely related to that of the 'public sphere' as defined by Habermas (1962): a historical space between the private domain and the state, where citizens could engage as equals in critical discussion about the state and society and influence their development in the process. In the words of Habermas (1962, xi), this was 'a sphere in which state authority was publicly monitored through informed and critical discourse by the people'. However, he saw the public sphere as something specific to bourgeois society in the late eighteenth and early nineteenth centuries, inextricably linked to face-to-face conversations between small groups of middle-class citizens, undisturbed by the mass media and their commercialization. The classic locus of the Habermasian public sphere was a café or salon where people engaged in debates about art and literature. By contrast, my interest is in contemporary public debate, regardless of whether it is face-to-face or through the mass media and specifically how it affects natural resource management.

Finally, Putnam's work on civil society and social capital is highly relevant for this book (Putnam 2000; Putnam et al. 1994). Drawing on the tradition of de Tocqueville, he sees civil society (including activities like bowling or visiting friends) as helping to create social capital in the form of trust and shared values (Putnam 2000). According to this line of thought, a society with a high level of social capital is more cohesive and functions better. The main connection between an active civil society and good governance is the presence of stronger networks, norms and trust, which enable society and the state to work together constructively, resulting in better governance (Putnam et al. 1994). 
By referring to 'public brainpower', rather than simply recycling the terminology of Dahl, Habermas or Putnam, I aim to highlight the capacity of the public to aid decision-makers in the governance of society: the strengths inherent in a diverse civil society and public debate, and on which the state can draw to govern more effectively. A polycentric society is brimming with tensions and contradictions, and the sum of its oftenopposing parts constitutes a capacity for thought not found among narrower elites on their own. In a thriving democracy, this point may seem obvious, even banal-but in many nondemocratic states, decision-makers seem unaware of such a perspective. The international discourse about democracy and free speech that such leaders normally encounter is concerned with human rights and their infringement, that is to say, with ethics. This book focuses instead on free speech as a tool for effective management of natural resources.

\section{Sources of Inspiration}

An important source of inspiration for the hypothesis outlined above is the case of Norwegian petroleum governance. The strength of institutions in Norway seems to lie not primarily in their design or content, but in the open and dynamic public debate in which they are embedded. It appears that Norway has been relatively successful in developing good institutions because it has open public debates that function as a continuous collective brainstorming for the creation of new institutions while securing public scrutiny of existing ones. The unfettered involvement of many independent actors in the public debate ensures a broad and varied base for conceiving new institutions, checks and balances on existing institutions, and the continuous evolution of institutions apace with the shifting needs of society and of the petroleum sector (see Berrefjord and Heum 1990, 34).

Norwegian petroleum institutions are constantly evolving and adapting to new conditions and knowledge. Changes in these institutions just in the period 2006-2016 affected almost every level of the country's petroleum governance system: the tax deductibility of oil exploration costs, the share of state ownership of the national oil company, the 
opening and closure of geographical areas for oil and gas exploration, investment rules for the sovereign wealth fund and limits on how much of the fund can be spent each year. Both the frequency of such changes and the broad public debate preceding them are indicators of dynamism.

Within the Norwegian context, a particular source of inspiration for this book has been the aid programme 'Oil for Development', launched in 2005. Through this programme, the Norwegian Agency for Development Cooperation (NORAD) assists prospective oil-producing states in getting a good start and trying to avoid the resource curse by supporting the development of petroleum-sector institutions before the oil revenue start pouring in. In practice, much of the work of this aid programme has been implicitly or explicitly about how to emulate Norway's institutions of petroleum governance. During the early years of the programme, petroleum-sector institutions tended to be treated as something that could be copied from one country to another-with some adjustment for local conditions, but without any attempts to alter the broader socio-political context in those countries (NORAD 2012, 1-3; Lopez Peralta 2009, 78; Flemming et al. 2007; Ekern 2005). One reason seems to have been the requirement that the aid programme be demand-driven, with the recipient states having the final say over its content. The governments of recipient states were not necessarily interested in complicated information about the Norwegian socio-political system that might also raise questions about their own rule. Quick technocratic petroleum-sector fixes seemed more attractive.

In addition to the efforts of the Oil for Development programme to spread the gospel of Norwegian petroleum-sector institutions, there have been cases of countries trying on their own initiative to emulate the successful institutions of Norway. For example, the USD 880 billion Norwegian oil fund - formally the foreign assets branch of the Norwegian Pension Fund-has been cited as an important source of inspiration for the sovereign wealth funds of countries such as Azerbaijan and Kazakhstan (Tsani 2015, 95; NBIM 2017; Ramirez-Cendrero and Wirth 2016). According to Olsen and Peters (1996, vii), 'public organizations in one country sometimes are able to learn from their peers in other countries' (emphasis added). However, as argued by Humphreys and Sandbu (2007, 
226), the political and institutional context may be decisive for the performance of such funds. As long as Azerbaijan and Kazakhstan have socio-political contexts fundamentally different from those of Norway, their institutions cannot necessarily be expected to function like those of Norway.

Countries that attempt to emulate others risk falling into the same trap as the Soviet Union. Although the USSR excelled at basic natural science and was reasonably successful as an industrial manufacturer, it was weaker when it came to generating its own new technologies (Balzer 1989). Individual scientists and citizens had original ideas, but, apart from military applications, few of these ideas were ever developed into massproduced products available to the Soviet population, let alone the world market. Even the first Soviet nuclear bomb, detonated in 1949, drew significantly on espionage carried out by the 'Cambridge Five' for the Soviet Union (Weinstein and Vassiliev 1999, 180-185).

While the Soviets were busy copying, the capitalist countries moved on, generating new technologies, consumer goods and levels of welfare. This has implications for nondemocratic states that are now attempting to emulate successful institutions of natural resource governance in democratic societies, some of which are included among the country-case studies in this volume. As institutions are more dependent on context than are physical technologies, the would-be authoritarian emulators of the resource governance institutions of open societies may have an even harder time than the Soviets did. The problem with such emulation may be its superficiality. As argued above, the strength of institutions in a country like Norway lies not in their formal characteristics, which can readily be observed, but in the open and dynamic public debate in which the institutions are rooted and which may not be immediately noticeable if the focus remains on the institutions.

A few sources provide some support for the hypothesis of Public Brainpower. Ostrom $(2005,29)$ argues that attempts to create new institutions are often based on 'naïve ideas' about good and bad institutions that fail to take into account how different institutions actually perform in specific contexts. Collier and Hoeffler $(2009,1)$ hold that it is not democracy as such, but checks and balances that enable countries to manage their natural resources sensibly. Korhonen (2004, 34) reasons 
that greater political freedom and improved education leads to better institutions and improves a resource-rich country's long-term growth potential. Ahmadov et al. $(2012,11)$ contend that avoidance of the resource curse depends on transparency and accountability in revenue management.

\section{Polycentricity and Resource Management: A First Glance at the Relationship}

Existing datasets provide some initial pointers on the issues dealt with in this book. Figure 1.1 plots indicators related to the scope for public debate in society (independent variable) against indicators related to governance of natural resources (dependent variable). This is solely for exploratory illustrative purposes and the choice of indicators used in the scatterplots is based on what data happened to be available.

All four scatterplots show considerable correlation between the paired variables using Pearson's product-moment correlation coefficient: freedom of press and budgetary openness $(r=0.61)$; political rights and resource governance $(r=0.80)$; personal freedom and resource governance $(r=0.81)$; freedom and non-corruption $(r=0.77)$. This provides a preliminary indication that the hypothesis may be correct and that public debate does indeed have a powerful effect on natural resource governance.

Such simple correlations do not necessarily reflect causal relationships between the variables on the $\mathrm{x}$ - and y-axes. One way of moving beyond the correlations would be to run multivariate regressions on large numbers of countries and variables, in order to narrow down the causal relationships. This is the type of exercise Haber and Menaldo (2011) did in their much-quoted article arguing that natural resource wealth does not necessarily lead to authoritarianism. However, such analyses are not unproblematic (see Papaioannou and Siourounis 2008, 366, 370; Andersen and Ross 2014). A central issue is whether the second-hand data normally used for such analyses actually represent what they are assumed to represent (Mitchell 2009, 423). 


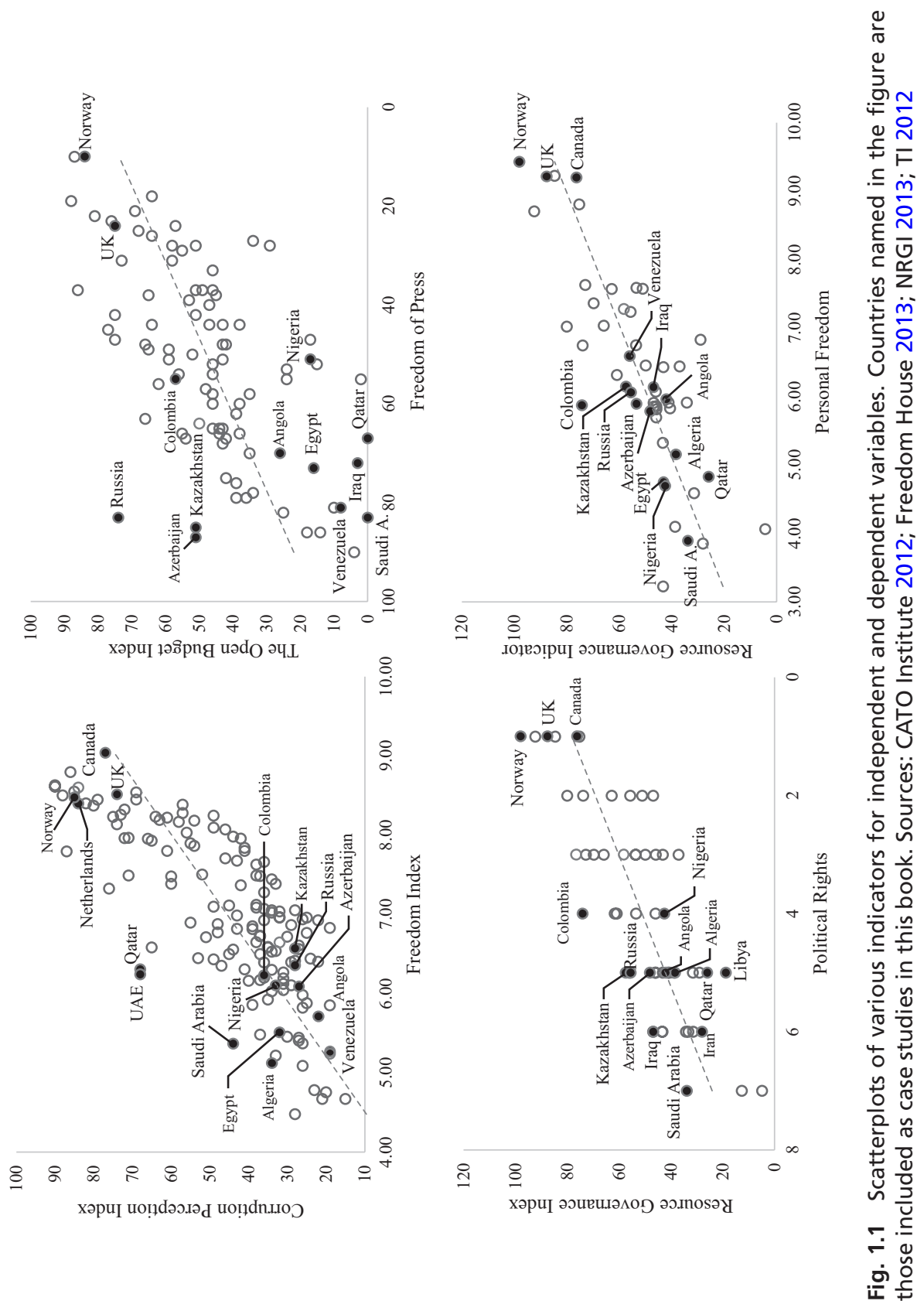


An alternative approach is to study individual cases in detail, in order to understand each of them in some depth. This approach has its own weaknesses - not least the subjectivity of those conducting the study and the difficulty of generalizing from one case to another. Such an approach is therefore not necessarily better than a multivariate regression, but it can be useful for exploratory purposes and for attempting to pin down causal relationships.

\section{Country Case Studies}

For the purposes of this book, I selected 18 countries and invited relevant researchers to provide empirical input on them in the form of chapters for the book. All the countries are major oil and/or gas producers, so in the rest of the book, the natural resource governance issues raised in this introductory chapter are examined through the lens of the petroleum sector. There are two main reasons for this choice. Firstly, it makes the case studies more comparable with each other. Secondly, few natural resources and opportunities in the world have been wasted on a scale similar to that of petroleum revenues, so understanding how to govern them more effectively is a matter of considerable importance. Together, the 18 countries stand for most of the world's oil exports and much of its petroleum history. The aim is still to provide analysis and draw conclusions that are also relevant for the governance of other natural resources. As a general theoretical concept, public brainpower may even be relevant for a country such as China, where the authorities appear to resist the involvement of the broader public in decision-making.

For comparative purposes, the selection of countries was made as diverse as possible on as many dimensions as possible (see Fig. 1.2). The countries differ on several variables. To ensure geographical and cultural variety, at least two countries were included from each of the world's major oil- and gas-producing regions: the Arab/Persian Gulf, the former Soviet Union, Latin America, North Africa, the Organisation for Economic Co-operation and Development (OECD) countries and subSaharan Africa. Thus, the case studies include developed, middle-income and developing economies; democratic and nondemocratic regimes; 


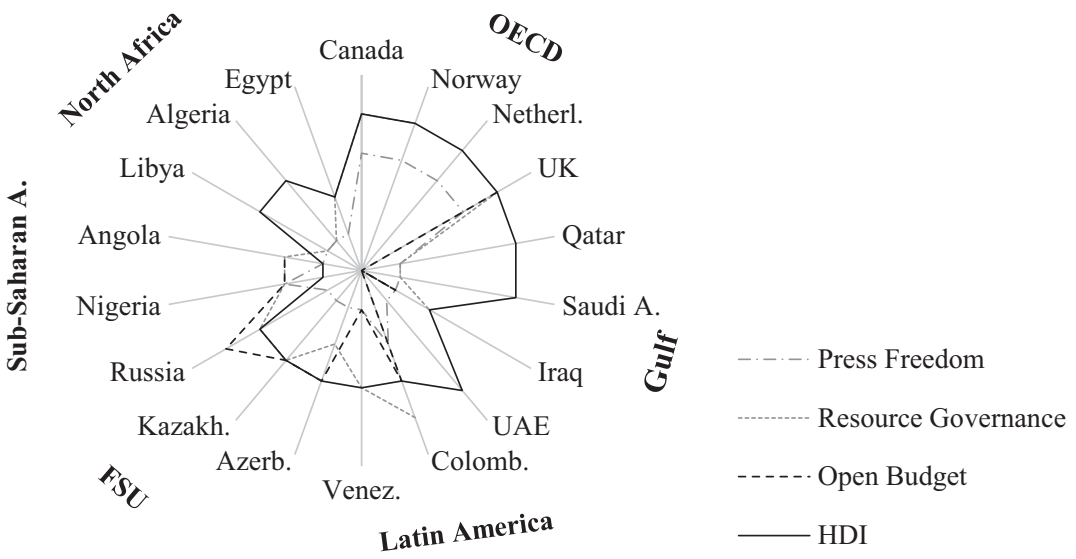

Fig. 1.2 Variation in country cases. The centre of the diagram represents low scores, the outer parts high scores. Sources: Freedom House 2016a, b; World Bank 2015; IBP 2016; UNDP 2014; Revenue Watch Institute 2013

countries ranked high and low on democracy, freedom of speech, governance and corruption indices; members and non-members of Organization of the Petroleum Exporting Countries (OPEC), the EU and the International Energy Agency; as well as countries with predominantly Catholic, Muslim, Orthodox Christian and Protestant populations.

Although it can be useful to categorize these countries along many dimensions as I have done above, each country has its own unique history and setting for the interaction between civil society and the petroleum sector. Iraq is a war-torn country that experienced a US-led invasion and that continues to suffer from ethno-sectarian violence and the meteoric rise and fall of the Islamic State. Venezuela had 17 years of left-wing rule under former president Hugo Chávez and his successor Nicolás Maduro and suffers from the political polarization of its society. Egypt was a significant oil exporter in the 1980s and 1990s but became a net oil importer around 2010 and is haunted by the legacy of former president Hosni Mubarak and the Arab Spring. Russia stands out as a former superpower with 70 years of Soviet history followed by a period of lawlessness in the 1990s and then growing authoritarianism under President Vladimir Putin. Even between Norway and the UK, there is a stark contrast in approaches to the petroleum sector and the involvement of the public in 
policy formulation, despite the fact that both countries are West European constitutional monarchies with strong cultural and social ties and have successfully coordinated the development of the North Sea petroleum province across their shared maritime boundary.

Examining and comparing such diverse countries can yield a multitude of perspectives on the relationship between public debate and the management of petroleum resources. The many dimensions on which the countries vary make it possible to take into account factors other than civil society which may affect the management of petroleum resources. If the aim were to test the hypothesis through a multivariate regression, some of the dimensions would be used for the regression itself and the others might be used as control variables. While this study instead attempts a qualitative, case-study approach, it is still helpful to consider the various dimensions in order to understand their role in each of the case studies.

\section{Definitions and Analytical Building Blocks}

For the purposes of this book, 'civil society' is defined as the sum of autonomous social actors (individuals and groups) who interact with and exert influence over the state and society (Cox 1999; Hearn 2001). For further discussion of the definition of civil society and some alternative approaches, see Heinrich (2005), Edwards (2004) and Evers and Laville (2004).

'Public debate' is defined as the expression of views on matters that are of concern to the public_-often, but not always, with opposing or diverging views being expressed by participants in the discussion. Public debate takes place mostly through the mass media, but also at meetings or through social media, academic publications and government policy documents (for further discussion of the understanding of public debate, see Reichborn-Kjennerud 2014 and Barkho 2016).

The terms 'governance' and 'management' of the petroleum sector are used interchangeably. Drawing on Lahn et al. $(2007,17)$ and Hults $(2012,62)$, 'petroleum sector governance' is defined as the socio-political system for making and implementing policy on the exploitation of oil 
and gas resources. 'Good governance' of the petroleum sector or of natural resources is defined as translating them into a high human development index score for a sustained period while limiting environmental harm.

The case-study contributors were asked to map the public debate and the role of different actors in influencing how oil and gas resources and revenue are managed. Three levels of analysis relevant for this mapping can be distinguished: (1) the different types of civil society actors that may contribute to public debate, (2) the petroleum governance issues that may be subject to debate and (3) the institutions of petroleum governance responsible for handling these issues. The three next paragraphs discuss these three levels.

The contributors were asked to examine the roles of the following types of civil society actors in the public debate on oil and gas governance: companies, educational institutions, foreign NGOs and international organizations, local and national NGOs, individual citizens, the mass media, political parties, religious organizations, think-tanks, trade unions and universities. The following questions were posed about these actors: What role does each type of actor play in influencing how petroleum resources and revenues are managed in your country? Are there any examples of success in influencing the management of petroleum resources? In what ways are non-state actors hindered in influencing petroleum governance?

The list of petroleum governance issues that might be subject to public debate and influence, and thus covered by the case studies, is long and includes topics as diverse as the level of taxation on oil and gas, corruption and peak oil (see Table 1.1). ${ }^{5}$

Various institutions might deal with these areas of petroleum governance, some of the most obvious being national oil companies, petroleum ministries and directorates, national geological surveys, environmental agencies, central banks and sovereign wealth funds. For the purposes of this book, an 'institution' is defined as a formalized organization; it should be dedicated to one or more specific purposes, have a name and identifiable employees or members, and its existence should be anchored in a written mandate or other text. 


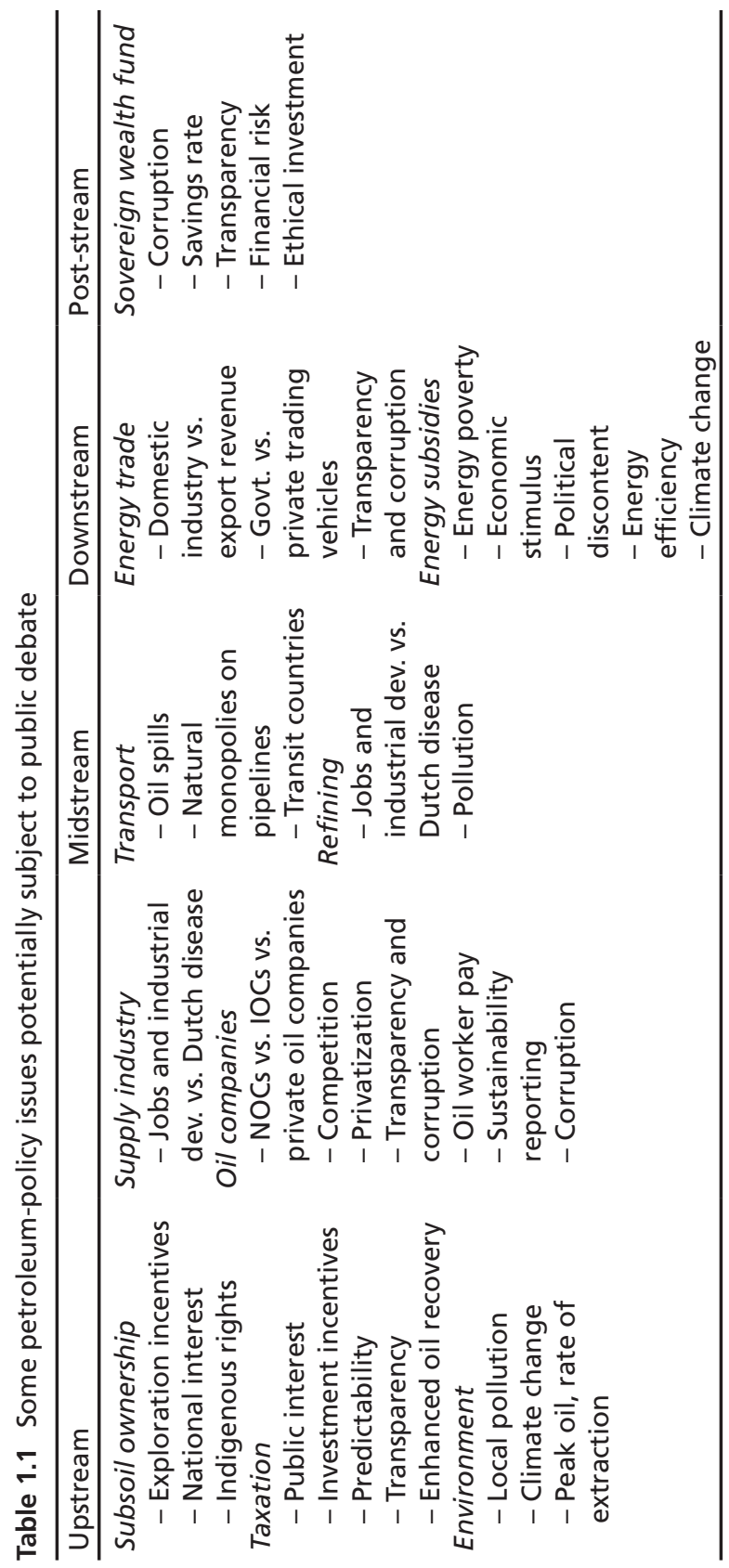


This contrasts with the significantly broader definitions employed elsewhere in the social science literature. For example, Huntington (1965, 394) defines institutions as 'stable, valued, recurring patterns of behavior'. Giddens $(1984,24)$ sees institutions as 'enduring features of social life', including modes of discourse, political institutions, economic institutions and legal institutions. According to North (1990,3), 'Institutions are the rules of the game in a society or, more formally, are the humanly devised constraints that shape human interaction.' Finally, drawing on North, Menaldo $(2016,81)$ defines 'institutions' as 'the matrix of incentives, constraints, opportunities and beliefs that represent the formal and informal rules of the game'.

Such broad definitions make it hard to see the difference between institutions and culture, social structure or society as such. With such definitions, it is difficult to see why the term 'institution' is needed at all. As a central concern of this book is the relationship between the broader societal context and the institutions of petroleum governance, using a definition that does not distinguish between them could create complications. Furthermore, narrow definitions of social science concepts are generally advantageous because they enable more precise analysis. All-encompassing and diffuse social science definitions of terms like 'institution', 'security' or 'power' sometimes seem driven by the desire of those working in a given subject area to make that area as big and important as possible, rather than to produce incisive analysis.

Some case-study contributors found their task daunting, as civil society and public debate are hardly allowed at all in their countries. In such cases, I asked the contributors to at least try to find out what views or thoughts the population might have contributed to a public debate if it had been allowed-in other words, what repressed views might exist below the surface. However, in some cases even this was difficult to write much about. In many countries, decision-making and policy formulation are so closed and public debate so repressed that it is scarcely feasible to find examples of anyone outside key government organs even attempting to think aloud about how the country's resource wealth should be managed. That is in itself an important finding that speaks directly to the hypothesis of this book: in some petroleum-rich countries, civil society and public debate play hardly any role in the governance of petroleum 
resources. According to the hypothesis, in such countries, long-term petroleum governance should be weak.

The rest of the book explores the strength of the hypothesis and its supporting arguments through systematic empirical analyses of petroleum-policy issues in the 18 selected oil- and gas-producing countries. As noted, all these countries are or have been among the world's major oil and gas producers, and thus have much to gain from handling their resources wisely. However, many of them have not.

The penultimate chapter offers highlights from the case-study chapters. The concluding chapter returns to the hypothesis presented in this introductory chapter, ranks 33 resource-rich countries on their success in maximizing their public brainpower, and proposes some tenets for how states can maximize the benefits of free speech and public debate for their own capacity to govern.

\section{Notes}

1. Value in 2015 USD, based on data from EIA (2017) on cumulative oil production and value estimated according to oil price and inflation for each year.

2. Engerman and Sokoloff $(1997,2002)$ argue that differences in natural endowments, especially agricultural resources, have affected the development of institutions. Dell (2010) counters this view with special reference to Peru. Ross (2001) and Tsui (2011) look at oil and Wantchekon (2002) at primary exports; all find that resource dependence is associated with lower levels of democracy and argue that this is due to resource abundance. Wiens $(2014,198)$ creates a formal model to show that resource revenue makes it difficult to develop strong institutions. Haber and Menaldo (2011) launch a critique of this literature, and of the work of Ross in particular, arguing that most of the findings are due to methodological weaknesses in the regressions applied. For more a detailed overview of this literature, see Boschini et al. $(2013,22)$.

3. Bulte et al. (2005), Corrigan (2014, 18), Islam (2003), Knack and Keefer (1995), Korhonen (2004, 7, 31), Mehlum et al. (2006) and Robinson et al. (2006) all seek to demonstrate through large-N studies that governance and institutional quality play a decisive role in economic growth and development. 
4. Al-Ubaydli (2012), Andersen and Aslaksen (2013) and Ross (2012) all argue that the decisive factors are the quality and strength of institutions before the flow of natural resource revenue starts: countries with weak institutions are more likely to suffer from the resource curse. Countering Sachs and Warner's (1995) claim that institutions are not important because resource revenues are not associated with institutional decay, Mehlum et al. $(2006,3)$ hold that the role of institutions cannot be dismissed altogether. They hold that states with 'producer-friendly' institutions handle resources well, while those with 'grabber-friendly' institutions handle them badly and tend to become poorer. Boschini et al. $(2007,593)$ argue that whether natural resources are bad for development or not depends not only on the strength of institutions, which they refer to as 'institutional appropriability', but also on the type of natural resource, especially its 'technical appropriability'. Kolstad and Wiig (2008) find that transparency is a necessary but not sufficient condition for reducing corruption.

5. On the importance of decision-making on some of the petroleum-policy issues listed, see Stiglitz $(2005,14,16,17)$.

\section{References}

Ahmadov, Ingilab, Anton Artemyev, Kenan Aslanly, Ibragim Rzaev, and Ilkham Shaban. 2012. How to scrutinise a Production Sharing Agreement: A Guide for the Oil and Gas Sector Based on Experience from the Caspian Region. http://pubs.iied.org/pdfs/16031IIED.pdf. Accessed on 26 February 2017. Almond, Gabriel Abraham, and Sidney Verba. 1965. The Civic Culture: Political Attitudes and Democracy in Five Nations. Boston, MA: Little, Brown.

Al-Ubaydli, Omar. 2012. Natural Resources and the Tradeoff between Authoritarianism and Development. Journal of Economic Behaviour and Organization 81 (1): 137-152.

Andersen, Jorgen, and Silje Aslaksen. 2013. Oil and Political Survival. Journal of Development Economics 100 (1): 89-106.

Andersen, Jorgen, and Michael Ross. 2014. The Big Oil Change: A Closer Look at the Haber-Menaldo Analysis. Comparative Political Studies 47 (7): 993-1021.

Balzer, Harley. 1989. Soviet Science on the Edge of Reform. Boulder, CO: Westview. 
Barkho, Leon. 2016. Academia and Public Debate. Journal of Applied Journalism and Media Studies 5 (2): 145-149.

Bebbington, Anthony. 2013. Natural Resource Extraction and the Possibilities of Inclusive Development: Politics across Space and Time. ESID Working Paper No. 21. http://www.effective-states.org/wp-content/uploads/working_papers/ final-pdfs/esid_wp_21_bebbington.pdf. Accessed on 25 October 2016.

Berrefjord, Ole, and Per Heum. 1990. Political Governance of the Petroleum Industry: The Norwegian Case. In Naive Newcomer or Shrewd Salesman? Norway-A Major Oil and Gas Exporter, ed. Helge Ole Bergesen and Anne Kristin Sydnes, 28-48. Oslo: Fridtjof Nansen Institute.

Boschini, Anne, Jan Pettersson, and Jesper Roine. 2007. Resource Curse or Not: A Question of Appropriability. Scandinavian Journal of Economics 109 (3): 593-617.

- 2013. The Resource Curse and its Potential Reversal. World Development 43: 19-41.

Bulte, Erwin H., Richard Damania, and Robert Deacon. 2005. Resource Intensity, Institutions and Development. World Development 33 (7): 1029-1044.

CATO Institute. 2012. 2012 Freedom Index Rankings. http://www.cato.org/ human-freedom-index. Accessed on 20 April 2016.

Collier, Paul, and Anke Hoeffler. 2009. Testing the Neocon Agenda: Democracy in Resource-Rich Societies. European Economic Review 53 (3): 293-308.

Corrigan, Caitlin. 2014. Breaking the Resource Curse: Transparency in the Natural Resource Sector and the Extractive Industries Transparency Initiative. Resources Policy 40: 17-30.

Cox, Robert W. 1999. Civil Society at the Turn of the Millennium: Prospects for an Alternative World Order. Review of International Studies 25 (1): 3-19.

Dahl, Robert. 1956. A Preface to Democratic Theory. Chicago, IL: University of Chicago Press.

- 1989. Democracy and its Critics. New Haven, CT: Yale University Press. Dell, Melissa. 2010. The Persistent Effects of Peru's Mining Mita. Econometrica 78: 1863-1903.

Edwards, M. 2004. Civil Society. Cambridge: Polity Press.

EIA. 2017. Short-Term Energy Outlook. 7 February. https://www.eia.gov/forecasts/steo/report/global_oil.cfm. Accessed on 2 February 2017.

Ekern, Ole. 2005. The Norwegian Assistance to the Petroleum Sector: A State-ofthe-art Study. Evaluation Report for NORAD. Oslo: NORAD.

Engerman, Stanley L., and Kenneth L. Sokoloff. 1997. Factor Endowments, Institutions, and Differential Paths of Growth among New World Economies. 
In How Latin America Fell Behind, ed. Stephen Haber, 260-304. Stanford, CA: Stanford University Press.

2002. Factor Endowments, Inequality and Paths of Development among New World Economies. Economia 3 (1): 41-109.

Evers, A., and J.-L. Laville. 2004. Defining the Third Sector in Europe. In The Third Sector in Europe, ed. A. Evers and J.-L. Laville, 11-41. Cheltenham: Edward Elgar.

Flemming, Ole Rasmussen, Kristine Bak, Kennet Majlund Larsen, and Jens Skov-Spilling. 2007. Evaluation of the Norwegian Petroleum-Related Assistance: Case Studies Regarding Mozambique, Bangladesh, East Timor and Angola. Evaluation Report for NORAD. Oslo: NORAD.

Freedom House. 2013. Charts and Graphs. https://freedomhouse.org/report/ freedom-world-2013/charts-and-graphs. Accessed on 22 April 2016.

— 2016a. Freedom in the World Classification. https://freedomhouse. org/report-types/freedom-world. Accessed on 19 October 2016.

- 2016b. Freedom of the Press. https://freedomhouse.org/report-types/ freedom-press. Accessed on 19 October 2016.

Giddens, Anthony. 1984. The Constitution of Society: Outline of the Theory of Structuration. Cambridge: Polity Press.

Haber, Stephen, and Victor Menaldo. 2011. Do Natural Resources Fuel Authoritarianism? A Reappraisal of the Resource Curse. American Political Science Review 105 (1): 1-26.

Habermas, Jürgen. 1962. The Structural Transformation of the Public Sphere: An Inquiry into a Category of Bourgeois Society. Cambridge, MA: MIT Press.

Hearn, Julie. 2001. The "Uses and Abuses" of Civil Society in Africa. Review of African Political Economy 28 (87): 43-53.

Heinrich, V.F. 2005. Studying Civil Society across the World: Exploring the Thorny Issues of Conceptualization and Measurement. Journal of Civil Society 1 (3): 211-228.

Hults, David. 2012. Hybrid Governance: State Management of National Oil Companies. In Oil and Governance: State-Owned Enterprises and the World Energy Supply, ed. David Victor, David Hults, and Mark Thurber, 62-120. Cambridge: Cambridge University Press.

Humphreys, Macartan, and Martin Sandbu. 2007. The Political Economy of Natural Resource Funds. In Escaping the Resource Curse, ed. Macartan Humphreys, Jeffrey Sachs, and Joseph Stiglitz, 194-233. New York: Columbia University Press.

Huntington, Samuel. 1965. Political Development and Political Decay. World Politics 17 (3): 386-430. 
IBP. 2016. Open Budget Index. http://www.internationalbudget.org/openingbudgets/open-budget-initiative/open-budget-survey/country-info/. Accessed on 19 October 2016.

Islam, Roumeen. 2003. Do More Transparent Governments Govern Better? Policy Research Working Paper 3077. Washington, DC: World Bank. http://documents.worldbank.org/curated/en/568401468741328131/109509322_2004 1117183019/additional/multi0page.pdf. Accessed on 6 November 2016.

Karl, Terry Lynn. 1997. The Paradox of Plenty: Oil Booms and Petro-States. Berkeley: University of California Press.

Knack, Stephen, and Philip Keefer. 1995. Institutions and Economic Performance: Cross-Country Tests Using Alternative Institutional Indicators. MPRA Paper 23118. http://homepage.ntu.edu.tw/-kslin/macro2009/Knack\&Keefer_1995. pdf. Accessed on 6 November 2016.

Kolstad, Ivar, and Arne Wiig. 2008. Is Transparency the Key to Reducing Corruption in Resource-Rich Countries? World Development 37 (3): 521-532. Korhonen, Likka. 2004. Does Democracy Cure a Resource Curse? BOFIT Discussion Paper 18. https://papers.ssrn.com/sol3/papers.cfm?abstract_ id $=2792024$. Accessed on 6 November 2016.

Lahn, Glada, Valérie Marcel, John Mitchell, Keith Myers, and Paul Stevens. 2007. Report on Good Governance of the National Petroleum Sector. https:// www.chathamhouse.org/sites/files/chathamhouse/public/Research/ Energy\%2C\%20Environment\%20and\%20Development/ggreport0407. pdf. Accessed on 11 March 2017.

López Peralta, Paulina Isabel. 2009. Olje for utvikling: En analyse av norsk petroleumsbistand. MA Thesis, University of Bergen, Norway.

Mehlum, Halvor, Karl Moene, and Ragnar Torvik. 2006. Institutions and the Resource Curse. The Economic Journal 116: 1-20.

Menaldo, Victor. 2016. The Institutions Curse: Natural Resources, Politics and Development. Cambridge: Cambridge University Press.

Mitchell, Timothy. 2009. Carbon Democracy. Economy and Society 38 (3): 399-432.

NBIM. 2017. Oljefondets markedsverdi. https://www.nbim.no/no/. Accessed on 14 September 2017.

NORAD. 2012. Evaluering av Olje for Utvikling-programmet. https://www. norad.no/globalassets/import-2162015-80434-am/www.norad.no-ny/ filarkiv/vedlegg-til-publikasjoner/sammendrag-av-evaluering-av-olje-forutvikling-programmet.pdf. Accessed on 24 October 2016.

North, Douglass. 1990. Institutions, Institutional Change, and Economic Performance. Cambridge: Cambridge University Press. 
NRGI. 2013. The 2013 Resource Governance Index. http://www.resourcegovernance.org/resource-governance-index/downloads\#data. Accessed on 22 April 2016.

Olsen, Johan, and Guy Peters. 1996. Lessons from Experience: Experiential Learning in Administrative Reforms in Eight Democracies. Oslo: Scandinavian University Press.

Ostrom, Elinor. 2005. Understanding Institutional Diversity. Princeton, NJ: Princeton University Press.

Papaioannou, Elias, and Gregorios Siourounis. 2008. Economic and Social Factors Driving the Third Wave of Democratization. Journal of Comparative Economics 36 (3): 365-387.

Putnam, Robert. 1995. Bowling Alone: America's Declining Social Capital. Journal of Democracy 6: 65-78.

- 2000. Bowling Alone: The Collapse and Revival of American Community. New York: Simon \& Schuster.

Putnam, Robert, Robert Leonardi, and Raffaella Nanetti. 1994. Making Democracy Work: Civic Traditions in Modern Italy. Princeton, NJ: Princeton University Press.

Ramirez-Cendrero, Juan, and Eszter Wirth. 2016. Is the Norwegian Model Exportable to Combat Dutch Disease? Resources Policy 48: 85-96.

Reichborn-Kjennerud, Kristin. 2014. Performance Audit and the Importance of the Public Debate. Evaluation 20 (3): 368-385.

Revenue Watch Institute. 2013. The 2013 Resource Governance Index: A Measure of Transparency and Accountability in the Oil, Gas and Mining Sector. http://www.resourcegovernance.org/sites/default/files/rgi_2013_Eng. pdf. Accessed on 19 October 2016.

Robinson, James A., Ragnar Torvik, and Thierry Verdier. 2006. Political Foundations of the Resource Curse. Journal of Development Economics 79: 447-468.

Ross, Michael. 2001. Does Oil Hinder Democracy? World Politics 53 (3): 325-361.

2012. The Oil Curse: How Petroleum Wealth Shapes the Development of Nations. Princeton, NJ: Princeton University Press.

Rosser, Andrew. 2006. The Political Economy of the Resource Curse: A Literature Survey. IDS Working Paper 268. http://www.ids.ac.uk/files/WP268.pdf. Accessed on 6 November 2016.

Sachs, Jeffrey, and Andrew Warner. 1995. Natural Resource Abundance and Economic Growth. NBER Working Paper 5398. http://www.nber.org/papers/ w5398.pdf. Accessed on 6 November 2016. 
Stiglitz, Joseph. 2005. Making Natural Resources into a Blessing Rather Than a Curse. In Covering Oil: A Reporter's Guide to Energy and Development, ed. Svetlana Tsalik and Anya Schiffrin, 13-19. New York: Open Society Institute. TI. 2012. Corruption Perception Index. http://www.transparency.org/cpi2012/ results. Accessed on 20 April 2016.

Tsani, Stella. 2015. On the Relationship between Resource Funds, Governance and Institutions: Evidence from Quantile Regression Analysis. Resources Policy 44: 94-111.

Tsui, Kevin K. 2011. More Oil, Less Democracy: Evidence from Worldwide Crude Oil Discoveries. Economic Journal 121 (551): 89-115.

UNDP. 2014. Human Development Index and its Components. http://hdr. undp.org/en/composite/HDI. Accessed on 19 October 2016.

Wantchekon, Leonard. 2002. Why do Resource Dependent Countries have Authoritarian Governments? Journal of African Finance and Economic Development 5 (2): 57-77.

Wiens, David. 2014. Natural Resources and Institutional Development. Journal of Theoretical Politics 26 (2): 197-221.

Weinstein, Allen, and Alexander Vassiliev. 1999. The Haunted Wood: Soviet Espionage in America: The Stalin Era. New York: Random House.

World Bank. 2015. World Bank Country and Lending Groups. https://datahelpdesk.worldbank.org/knowledgebase/articles/906519-world-bank-country-and-lending-groups. Accessed on 19 October 2016.

Open Access This chapter is licensed under the terms of the Creative Commons Attribution 4.0 International License (http://creativecommons.org/licenses/ by/4.0/), which permits use, sharing, adaptation, distribution and reproduction in any medium or format, as long as you give appropriate credit to the original author(s) and the source, provide a link to the Creative Commons license and indicate if changes were made.

The images or other third party material in this chapter are included in the chapter's Creative Commons license, unless indicated otherwise in a credit line to the material. If material is not included in the chapter's Creative Commons license and your intended use is not permitted by statutory regulation or exceeds the permitted use, you will need to obtain permission directly from the copyright holder. 